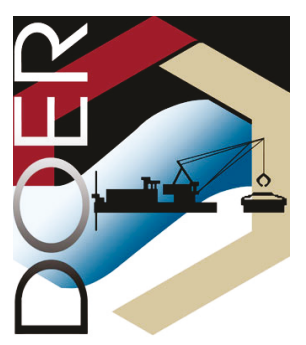

ERDC/TN DOER-E43

February 2019

\title{
Summary of Threatened and Endangered Species Team Workshop: ESA Section 7(A)(1) Conservation Planning in the South Pacific Division
}

by Michael P. Guilfoyle, Richard A. Fischer, and Jacob F. Jung

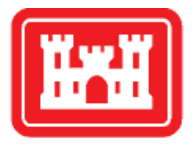

US Army Corps

of Engineers 8

Engineer Research and

Development Center
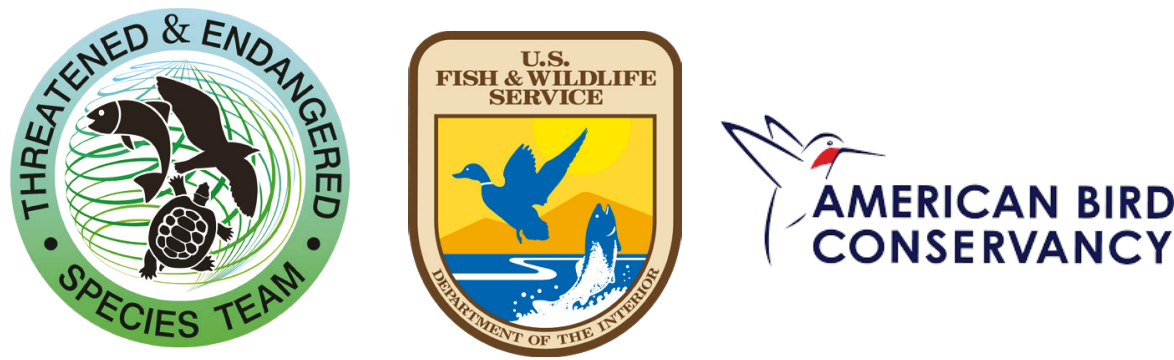

PURPOSE: This technical note $(\mathrm{TN})$ summarizes information presented at a regional workshop on the importance and application of the Endangered Species Act (ESA) Section 7(a)(1) conservation planning process within the U.S. Army Corps of Engineers (USACE) South Pacific Division. This workshop was held on 6-7 December 2016 on U.S. Marine Corps Base Camp Pendleton, California. The main objective of the workshop was to assemble an interagency and interdisciplinary group of wildlife biologists and managers to detail how Section 7(a)(1) consultation with the U.S. Fish and Wildlife Service (USFWS) and National Marine Fisheries Service (NMFS) can facilitate conservation planning of listed species on federal lands. Goals of this workshop included the following: (a) providing basic information on the function and process of Section 7(a)(1) conservation planning, (b) emphasizing the role of Section 7(a)(1) to support agency missions while promoting proactive conservation planning for federally threatened and endangered species (TES) recovery, (c) providing detailed examples of successful application of Section 7(a)(1) conservation planning on federal lands, and (d) identifying opportunities to facilitate and improve Section 7(a)(1) actions for future conservation efforts and for effective management and population recovery of TES inhabiting federal lands. The information provided in this TN is derived from presentations made during the workshop by representatives of the USACE, Department of Defense (DoD) Military Service Branches, USFWS, American Bird Conservancy (ABC), U.S. Geological Survey (USGS), U.S. Department of Agriculture-National Resources Conservation Service (NRCS), and National Oceanic and Atmospheric Administration (NOAA).

BACKGROUND: The ESA of 1973 provides framework regulated by the Department of the Interior to protect species listed as threatened or endangered in the United States and its territories. Identification and determination of listed species on federal lands requires significant expenditures in time and funds to devise effective management approaches for the protection of critical habitat requirements and eventual recovery of listed species. ESA Section 7(a)(1) calls for, and indeed mandates, proactive conservation planning for TES by federal agencies in consultation with the USFWS and NMFS. This proactive planning effort can be flexible and collaborative and is the best means to promote the conservation and recovery of listed species. 
Unfortunately, many federal agencies often devote most or all of their funding to ESA Section 7(a)(2) consultations. Section 7(a)(2) consultation generally provides little discretion by the action agency, is designed primarily to only maintain species baselines, and puts receiving agencies in a reactionary position. In addition, the process is largely inflexible, and can move the primary objective away from recovery of the listed species, and more towards avoiding jeopardy decisions that often lead to litigation and incur significantly higher costs. Efforts are ongoing within the DoD and USACE to implement improved response to, and management of, listed species on DoD lands. The formation of the USACE Threatened and Endangered Species Team (TEST) is designed to improve the organizational approach to increase operational flexibility, reduce costs, and promote completion of missions, while striving to recover TES. This effort represents a proactive, multi-agency collaborative approach to improve the conservation and management of all listed species on DoD lands. The following workshop presentations by wildlife biologists, managers and researchers from the USACE, USFWS, NRCS, and others, served to improve communication among federal agencies that manage and conserve TES. Open discussion periods involving participants from the audience and a selected panel of experts (see Appendix A for panel members) were held and are summarized to identify ongoing problems and conflicts with management and conservation of listed species. Conflict resolution and opportunities to implement Section 7(a)(1) conservation actions also were discussed.

\section{U.S. Fish and Wildlife Service and ESA Section 7(a)(1) (Paul Hartfield, USFWS MS}

Field Office). The purpose of the ESA of 1973 is to conserve the ecosystems that support TES, and to provide a program to protect and recover populations of those species (Section 2(b)). It was also the intent of Congress that all Federal agencies would apply their authorities to these purposes (Section 2(c)). A practical and cost-effective mechanism to achieve conservation of TES and their ecosystems was also clearly identified in the ESA. Titled Interagency Cooperation, Section 7 of the ESA directs all Federal agencies to share conservation duties and burdens through interagency cooperation and collaboration. Specifically, all Federal agencies with the ability to affect TES are directed to use their authorities to develop and carry out programs for the conservation of these species in consultation with FWS or NMFS, as appropriate (Section 7(a)(1)).

In practice, however, Federal agencies have focused upon Section 7(a)(2) of the ESA, which presents a bottom line, at the very least, all Federal agencies must ensure that their actions do not jeopardize the continued existence of any listed species or adversely modify their critical habitat. Subsequent amendments to the ESA and implementing regulations have contributed to this focus on the bottom line. Amendments to the ESA have included 15 subsections under Section 7 that detail the 7(a)(2) consultation process, components, and exemptions, while only a single sentence addresses Section 7(a)(1), and virtually no regulatory guidance exists for interagency cooperation to address collaborative, cost-effective conservation.

Regardless, the mandate (Section 2(c)) and authority (Section 7(a)(1)) for Federal agencies to conserve TES and their habitats remains, and has been affirmed by multiple legal decisions (e.g., TVA v. Hill, 1978; Sierra Club v. Glickman, 1985; Florida Key Deer v. Stickney, 1994; Florida Key Deer v. Brown, 2005, etc.). Despite decades of court cases and judicial reviews (e.g., Rohlf 2001; Wood 2004, etc.) recognizing the affirmative conservation duty of all Federal agencies, 
Section 7(a)(1) has not realized its potential to achieve cooperative and proactive conservation programming (e.g., Ruhl 1995).

The Federal agency cultural focus on Section 7(a)(2) has not promoted the Interagency Cooperation to conserve TES as envisioned by Congress. It is a strictly regulatory process, that once initiated, establishes deadlines and non-discretionary endpoints for the action agency. Section 7(a)(2) was never intended to be a conservation tool, as 7(a)(2) consultations are strictly concerned with facilitating Federal actions with negative effects to listed species within defined action areas. By this definition (and in practice), without positive conservation actions successive section 7(a)(2) consultations can erode a species baseline, progressively limit action agency management and mission options, and contribute to a future jeopardy call.

In contrast, Section 7(a)(1) instructs and authorizes Federal agencies to develop and implement a programmatic strategy (in coordination with FWS/NMFS) outlining how the action agencies authorities can and will be used to contribute to the recovery of listed species. It is a collaborative process, culminating in a series of discretionary actions and processes that are incorporated into the agencies mission as funding and resources allow. Due to the potential of Section 7(a)(1) to establish and implement management programs extending beyond postdelisting, it also provides opportunity for the recovery of conservation reliant species (Goble and Scott 2006; Goble et al. 2012).

Isolated cases of interagency cooperation have recently demonstrated the value and potential of the Section 7(a)(1) not only to conserve TES, but also to expand the Federal action agencies primary program options and flexibility under the $7(\mathrm{a})(2)$ consultation process. For example, the U.S. Marine Corps established a Section 7, Recovery and Sustainment Program (RASP) (U.S. Marine Corps 2012), to expand management options for the endangered Red-cockaded Woodpecker (RCW) (Picoides borealis). The Marine Corps was concerned that successive 7(a)(2) consultations would eventually impact future training options and capabilities on Camp Lejeune, NC. The goals of the RASP program were to positively contribute to RCW recovery while maintaining and expanding existing training areas. This program utilizes off-base collaborations to design spatial configurations of RCW clusters to promote successful establishment and reproductive success of the South Carolina RCW population.

The Lower Mississippi River Conservation Program (LMRCP) was established by the USACE Mississippi Valley Division to promote effective conservation of multiple listed species, including the endangered Interior Least Tern (Sternula antillarum), Pallid Sturgeon (Scaphirhynchus albus), and the Fat Pocketbook Mussel (Potamilus capax), while providing certainty and flexibility for their primary engineering mission of safe navigation and flood control (USACE 2013). The LMRCP was implemented through a collaborative Section 7 (a)(1) process that was later formalized as a conservation plan. The LMRCP recognizes that engineering of the main channel has reduced habitat complexity, and utilizes the channel engineering and maintenance processes to mitigate these losses, at little to no additional cost to the mission program. Collaboration with state agencies and non-governmental organizations has also minimized USACE program costs to plan and conduct habitat restoration efforts unrelated to the construction and maintenance program. This effort has not only benefited the three listed species, but also migratory birds, fisheries, and recreation, with no loss of the USACE flood control or navigation mission objectives. Due in large 
part to the management provided by LMRCP, the USFWS (2013) has recommended delisting the Interior Least Tern.

The USACE Memphis District has also utilized the Section 7(a)(1) process to conserve populations of the endangered Fat Pocketbook Mussel in the St. Francis River Floodway, AR. This effort, in collaboration with the USFWS and the Arkansas Game and Fish Commission, has resulted in construction and maintenance Best Management Practices (BMPs) and Standard Operating Procedures (SOPs) that minimize effects to local mussel populations. Survey and monitoring protocols also have been adapted to reduce cost while still allowing the District to address knowledge gaps for the St. Francis River fat pocketbook population. The St. Francis River Floodway Section 7(a)(1) process has also reduced the cost and time required for project specific Section 7(a)(2) consultations.

These examples highlight opportunities Section 7(a)(1) provides to collaboratively achieve TES conservation while minimizing interagency conflicts and costs. Section 7(a)(1) programs ensure institutional memory, regulatory compliance, and allow action agencies to address future challenges and opportunities. Where successfully implemented, Section 7(a)(1) programs lead to higher levels of Federal action agency stewardship, and result in improved species baseline status and recovery.

The USACE TES Team Approach: ESA Section 7(a)(1) and Conservation Planning for Listed Species (Richard Fischer, ERDC-EL). The DoD military services and USACE currently manage approximately 42 million acres of land in the United States, much less than many other federal agencies. However, in 2014, DoD and USACE expenditures on TES exceeded $\$ 330$ million; nearly $90 \%$ of these expenditures were spent on fish, particularly salmonids, $10 \%$ was on birds, and the remaining expenditures on mammals, reptiles, amphibians, plants, and invertebrates.

The USACE manages over 430 reservoir projects, including a multitude of inland and coastal navigation projects nationwide. As an agency, the USACE must address over 300 TES that occur on lands and in waters within their jurisdiction. An additional 200+ species listings and/or critical habitat designations are expected to occur by 2018. Although the USACE engages in more consultations than any other agency, there has not been an organized strategy to comprehensively address TES management and conservation. To date, most of the focus has been on single-species approaches with minimal or mixed results. Generally, USACE efforts have led to minimal easements of operational constraints due to conflicts with TES, and any positive contributions towards TES recovery goals, with few exceptions, have been limited or unquantified.

The ERDC established the TEST in 2014 to improve how the USACE addresses the conservation and management of TES under ESA Section 7. The purpose of TEST is to develop solutions to TES, and other sensitive species, issues that will, (1) improve operational flexibility, (2) reduce costs, (3) improve budget planning capabilities, (4) reduce impacts to mission implementation, and (5) improve species conservation outcomes. These purposes will be achieved by development of a comprehensive long-term strategy for addressing TES management on USACE lands. Efforts are being made to identify and document which TES have the largest impact to USACE missions, while identifying research needs that will most benefit TES populations, decrease mission impacts, and provide the highest return on investments. These efforts will involve identification of where to 
focus conservation planning actions using the ESA 7(a)(1) authority and establishing internal and external collaborative opportunities to meet stated goals. In addition, the TEST approach will include initiating proactive strategies to identify at-risk species likely to impact future USACE missions. A recent memorandum from USACE leadership has provided authority for USACE Districts to implement Section 7(a)(1) conservation planning for TES impacted by mission operations. Explicit conservation management agreements will be established for long-term TES management. An example of a collaborative effort using Section 7 (a)(1) between USACE, USFWS, and other agencies on the management of Interior Least Tern populations has resulted in the recent recommendation for delisting. Numerous opportunities for future collaborations exist, particularly in the southwestern United States, where various TES exist on federal lands managed by multiple federal agencies. For example, USACE lands under management for ripariandependent TES are adjacent to lands managed by the National Park Service, DoD, and U.S. Forest Service in the Los Angeles County Drainage Area, Santa Ana River/Prado Basin, Russian River, and American and Sacramento Rivers.

An effort to identify ranges and extent of TES on federal lands nationally has resulted in the USACE development of the Threatened and Endangered Species Web Portal (https://cesamusace.maps.arcgis.com/apps/webappviewer/index.html?id=c46790calc484535b29 8bef421a30779) where managers and researchers can use a Geographic Information Systems (GIS) map builder to overlay TES range maps with federal land ownership boundaries. The DoD also has established the Collaborative Wildlife Protection and Recovery Initiative (CWPRI), in collaboration with the DoD Readiness and Environmental Protection Integration (REPI) program, USFWS, Bureau of Land Management (BLM), NRCS, U.S. Forest Service, Bureau of Reclamation, and the National Fish and Wildlife Foundation. The CWPRI shares many objectives with TEST, including development of a strategy for implementing Section 7(a)(1) authority for long-term conservation planning, ensuring and leveraging the necessary resources, capabilities and tools needed to accomplish the strategy, implementing a proactive approach to protecting species and habitat, and enlisting stakeholders and partners to share limited resources. The NRCS and USFWS are collaborating to bridge the gap between federal and private lands through the NRCS Working Lands for Wildlife program.

\section{Rangewide Conservation Planning: ESA Section 7(a)(1) and the Recovery of the} Interior Least Tern (Casey Lott, ABC). There are currently about 100,000 Least Terns in North America. This species is migratory, breeding in North America and wintering in Central and South America, however, its wintering range and non-breeding habitat use is generally unknown. The interior population of Least Tern (ILT) is defined as any Least Terns that nest $>50 \mathrm{~km}$ from the Gulf of Mexico. The ILT was listed under the ESA in 1985, with habitat loss considered the primary reason for the decline. Habitat loss through changes in structure of riverine habitat for navigation purposes caused significant loss of suitable sand bar nesting habitat along the Missouri and Platte Rivers. This bird is one of the top five species in terms of USACE expenditures on listed species. The ILT nests on approximately 4,000 rivers miles in the interior U.S. Midwest, often along isolated stretches that are difficult to access and survey. The first range-wide surveys were conducted in 2005, sixteen distinct populations were identified based on dispersal information, where each population is separated by about $95 \mathrm{~km}$. There are approximately 17,500 ILT in 450 colonies, four of the sixteen populations support $98 \%$ of all 
adult birds and $95 \%$ of all known colonies. Various populations are found on numerous different dam, river and reservoir operations that encompass different missions for the USACE.

Recovery efforts historically have focused on actions recommended in USFWS Biological Opinions, including those for the Missouri, Arkansas, and Mississippi Rivers, this is the driving force in USACE expenditures. USACE Districts and USFWS Ecological Services Offices throughout the ILT range often are in conflict, performing different monitoring efforts and employing different management approaches, with no active recovery team having ever being established. Often, different regions and field offices are resistant to outside assistance and have not been able to collaborate well on recovery efforts. There is a fundamental mismatch between biological distribution of the terns and administrative boundaries and the ESA is intended to be implemented at the scale of the listed population. When full range-wide surveys were conducted in 2005, the ILT rangewide population was much larger than predicted, and most of the population targets established during listing in the 1980s had been met. As a result, the USFWS has recommended the ILT for delisting (USFWS 2013).

What went wrong? Population models used by USFWS and others routinely underestimated the survivorship of these terns. This caused the population models to repeatedly indicate that populations were declining, even while routine monitoring results were indicating that populations were increasing. Many population models are inherently biased and incorporate uncertainly which may preclude conclusive inference about population stability. Relevant information on the specific factors that limit population growth are needed. In the ESA, the heart of the status assessment is based on the following: (1) the present or threatened destruction, modification or curtailment of the habitat or range, (2) overutilization for commercial, recreational, scientific, or educational purposes, (3) disease or predation, (4) inadequacy of existing regulatory mechanisms, and (5) other natural or manmade factors affecting the existence of the species. The relevant spatial and temporal scales at issue include the whole range of the species and the status of the population into the foreseeable future. Conservation planning for ESA listed species require the adequate and sufficient representation (How does the species range across the entire historic, ecological and geographic ranges?), redundancy (is the species concentrated in multiple populations across large areas and within all known regions?), and resiliency (how does the habitat and life history of the species relate to ongoing degradation and population sustainability throughout the range?) (the 3 R's), which are described in the USFWS Recovery Handbook. When the ILT was assessed using these criteria, the USFWS determined that they are distributed throughout their known historic ranges, are located in many separate populations and colonies, and that the nesting habitat continues to experience sufficient renewal throughout the range. The ILT also is adapted to a longlife with significant opportunities for large reproduction outputs even after several years of failure due to inundated breeding habitat (USFWS 2013).

Section 7(a)(1) conservation planning efforts must conform to realities faced by the species in question. ESA recovery mandates must be related to geography, ecosystem function and threat abatement. The USFWS 5-factor analysis is the framework for evaluating threat abatement, and the 3 R's are recommended in this process. Physical geography and ecosystem degradation are often too costly to overcome in the foreseeable future. Long-term management agreements will be necessary for conservation-reliant species. The application of the Section 7(a)(1) approach is a team effort that starts with operations, all actions that affect a species, even positively, will need 
to be assessed in the conservation planning. Overall objectives need to raise species' baseline populations, avoid or minimize negative impacts, and institutionalize and assess BMP's to ensure the best outcome.

\section{What it Takes to be Successful in Pursing Section 7(a)(1) Programs (Stephen Ricks, USFWS, MS Field Office). Section 7(a)(1) conservation planning should be a flexible,} proactive, strategic, landscape-level implementation framework. The approach can create a conservation blue print for agencies and provide the context and framework for 7(a)(2) consultations. Ideally, the approach should target multiple species in the ecosystem, where targeted efforts can benefit other species including candidate specie and species of regional concern. However, each Section 7(a)(1) plan will be different for different species, agencies, and programs. Implementation of conservation planning can occur at both a programmatic or project level as well at the single species or multiple species level. Section 7(a)(1) conservation planning requires interagency collaboration. Cooperation is achieved in Section 7(a)(2) whereas collaboration occurs during Section 7(a)(1) interagency consultations. Declining budgets and staff often further encourages collaboration. When agencies proactively collaborate, outcomes are generally much better for the agencies and the species involved, with effective collaborations requiring negotiations and compromise. Collaboration will help limit duplication of efforts, ensure that tasks are completed while leveraging resources, and permit sharing of information. In the process, agencies need to be on the same page with a shared vision and clear goals. Consensus must rule in the decision making process and written interagency agreements can help facilitate collaboration and result in organizational change. Once the collaboration process has been established, all parties need to work together to evaluate progress and outcomes.

Numerous barriers can prevent or derail interagency collaborations: (1) Agency Mission and Objectives, different agencies have different missions and objectives. Knowledge of, and catering to, the specific mission requirements of partaking agencies can help foster an understanding of the shared needs for the collaboration. (2) Organizational Culture, shared values within an organization can have a strong influence on the people and dictate how they address, act, and perform their job. (3) Organizational language, words and acronyms can have similar appearance but different meanings; this can be a barrier to understanding issues at the very start. (4) Interagency history, people often forget the positive and focus on the negative. Each new collaboration should be viewed as a new start. Be positive in the initial consultations even if prior interactions have not fared well. (5) Individuals, attitudes and actions of specific individuals in any organization can derail organization decisions.

Overcome these potential barriers by establishing a shared vision that is mutually beneficial to all agencies involved. Maintain realistic expectations by understanding the structure and priorities of the other agencies. Utilize shared resources and authorities when possible, and work within the existing system. From the onset, start the collaboration with a willingness to trust each other. Maintain simple and clear communication and only promise what you can actually achieve. Remember, you should not go into this with a "win or lose" attitude - this is a negotiation and it will require compromise by all parties. And when the occasion arises, try to agree to disagree and move forward, don't let disagreements derail the collaboration- focus on the shared problem and how both agencies can come together to resolve it. Operate at the organization level and build trust by involving all key personnel. One can facilitate future collaborations by institutionalizing change 
in the process. This can be facilitated by including objectives into agency mandates, budgets, performance plans, etc. Any interagency collaboration needs to have a shared understanding of the problem, maintain a proactive, adaptable and realistic view of the situation, and define benchmarks and measurable criteria to assess success. When possible, publish the shared success- don't be afraid to brag on each other as it will go a long way.

Prior experience has resulted in several lessons learned: the path to success requires an understanding of interagency history and organizational culture. Operate at the appropriate organizational level (e.g., District, Region, etc.) and within the existing agency authorities. Know the chain of command and don't be afraid to approach upper management personnel if road blocks occur. Be prepared on all issues when initiating the collaboration.

Efforts on the Lower Mississippi River represent a good example. The problem that faced both agencies was how to incorporate TES conservation into the primary mission (flood control and navigation) of the USACE, Mississippi Valley Division (MVD). Agencies involved included the MVD, ERDC, and the USFWS, Southeast Region Mississippi Field Office. The scope of the effort extended from the confluence of the Ohio and Mississippi Rivers to New Orleans. The first action item was to seek the transfer of the lead USFWS effort for the Least Tern to the Mississippi Field Office. Although this was not necessary for our success, it resulted in the Mississippi Field Office having the national lead for two of the three listed species and the regional lead for the third in the action area. Next, a Strategic Habitat Conservation plan for the Lower Mississippi River was completed. This plan enabled the Service to communicate our vision for the conservation of the listed species. A Section 7(a)(1) conservation plan was then developed for the Interior Least Tern, Pallid Sturgeon, and the Fat Pocketbook Mussel. Consultation with the USACE channel improvement program was established to determine what operations were having the most negative impact on habitats of the listed species. Other documents that have followed include a Section 7(a)(1) integrated process review (after action report) developed in 2014. A Southeast Region Section 7(a)(1) framework that was finalized in 2015 by the USFWS to aid other Service field offices in applying Section 7(a)(1). A five-year review was written for the Interior Least Tern. This review recommends delisting due to recovery (recovery is credited to a much larger conservation effort that has occurred over several decades but the 7(a)(1) plan is a contributing factor). Success of this effort is discernible. The USACE and USFWS now have a memorandum to work together to improve effectiveness of the ESA by expanding the use of Section 7(a)(1) conservation planning. Moreover, the USACE leadership sent a memorandum to all Districts to improve the efficiency of project operations and ESA compliance by Section 7(a)(1) consultations.

\section{FEDERAL AGENCY INITIATIVES AND PROGRAMS}

Natural Resources Conservation Service (NRCS): The Working Lands Wildlife
Initiative (Thomas Moore, USDA-NRCS, Davis, CA). The U.S. Department of Agriculture, NRCS was started in 1935 in response to the Midwestern "Dust Bowl" with a focus to instruct farmers on better soil management approaches. In 1994, the mission of the agency was expanded to include air, water, and wildlife habitat on private lands in order to make these lands more sustainable. The agency has about 11,000 employees with $92 \%$ located in field offices. The agency focuses on private lands and is non-regulatory - all participation in agency programs by land owners is voluntary. The NRCS can provide financial assistance to land 
owners for implementation of conservation efforts, use of easements and rental agreements to achieve goals, and implement science-based approaches when possible. NCRS programs used to meet these goals include the Environmental Quality Incentive Program and the Wetland Reserve Program, each use easements to remove flooded agricultural lands from production and then restores wetland and riparian habitats. The Conservation Effects Assessment Program and Conservation Innovation Grants are programs that utilize the science of monitoring and measuring management impacts to identify actions that benefit wildlife populations.

The NRCS initiated the Working Lands for Wildlife (WLFW) program to promote effective species conservation on private lands. The number of species listed under ESA has increased significantly over that past few decades and trends for recovery status show that most listed populations continue to decline. Therefore, the NRCS has attempted to change the paradigm of conservation in order to be more effective in the recovery of listed populations with a focus on private lands. For conservation reliant species, this means to use policy changes plus voluntary action to have public lands facilitate conservation of listed species. The Greater Sage-Grouse (Centrocercus urophasianus) has been one species where this approach has been beneficial. This same approach is also being used for the Southwestern Willow Flycatcher (SWFL; Empidonax traillii extimus). Many species' needs are compatible with some agricultural practices.

The WLFW program is aligned to facilitate recovery of the SWFL by, (1) working with private landowners to conserve and enhance habitat on non-federal lands, (2) collaborating with tribal lands to work for conservation and recovery, and (3) investigating the impacts of grazing systems and other strategies for riparian ecosystem recovery and maintenance. This approach identifies historic or existing territories to increase nesting opportunities by enhancing riparian habitat and increasing connectivity of habitats in degraded landscapes. Funds for restoration of SWFL habitat have been procured through the USFWS and the California Department of Fish and Wildlife (CADFW). From 2012 to 2015, over $\$ 3.8$ million has been spent to enhance over 7,000 acres of habitat for this endangered flycatcher. The NCRS and the WLFW program is currently working with other states to promote recovery of other listed species. The NRCS is looking for opportunities to work with other federal partners to leverage habitat rehabilitation on both public and private lands. Benefits of this effort could (1) increase joint funding for riparian habitat enhancement, (2) expand technical assistance in southern California with partnerships with USFWS, CADFW, DoD, and non-governmental organizations, and (3) secure matching funds for easements or habitat enhancement through the DoD REPI Program. Collaborations with NRCS WLFW could help facilitate the recovery of other listed and species at risk, including the Greater Sage-Grouse, Tricolored Blackbird (Agelaius tricolor), Least Bell's Vireo (LBVI) (Vireo bellii pusillus), Western Yellow-billed Cuckoo (Coccyzus americanus), Burrowing Owl (Athene cunicularia), and Monarch Butterfly (Danaus plexippus).

\section{Department of Defense REPI and the Collaborative Wildlife Protection and Recovery Initiative (Ryan Orndorff, DoD, Washington, DC). The Department of} Defense (DoD) Readiness and Environmental Protection Integration (REPI) protects our Nation's military mission through cooperative land-use planning and integrated land protection with a variety of partners around installations and ranges. With these partners, REPI plays a key role in $\mathrm{DoD}$ efforts to combat encroachment from degrading military readiness. 
Encroachment is any external factor that can limit or restrict military training, testing, and operations. Preventing urban encroachment was the early emphasis of the REPI program. Housing developments located so close to base boundaries that neighbors complain about the noise and dust from military activity is an example of encroachment.

This early emphasis responded to rapid urbanization creeping closer and closer to military boundaries, especially in the 1990s. Once located in relative isolation, expanding urban growth is now surrounding the boundaries of numerous installations, including Marine Corps Base Camp Pendleton.

Despite the early emphasis on protecting DoD from incompatible development, REPI always has had an equally important mission of protecting DoD military activities from environmental restrictions. As REPI successfully buffered the exterior boundaries of installations and ranges from urban encroachment, DoD found itself internally encroached by the need to use lands within its boundaries to protect wildlife. As the need to protect wildlife increased, so did DoD's urgency to find locations outside its installations where it could support conservation to protect species.

Numerous ESA listed species are found on installations, and increasingly, they are isolated by the urbanization of the landscape. The presence of ESA species solely, or largely present on installations can create conflicts between environmental regulations to protect species and the requirement to meet national defense missions and objectives.

These conflicts can be reduced or eliminated by promoting partnerships that ensure the sustainability of ESA listed populations on lands bordering or outside of the installation. Section 7(a)(1) conservation planning for the Red-cockaded Woodpecker on Camp Lejeune is one successful example of this approach. When the stakeholders involved work towards collaboration, conflict tensions are reduced and collaboration ensures to benefit everyone including wildlife populations.

In its 2016 Report to Congress, REPI recapped its ten years of conservation progress in support of military readiness. In those ten years, \$591 million in DoD funds have been leveraged with $\$ 534$ million partner funds to protect over 437,000 acres and sustain military readiness at 88 installations in 30 states through compatible land projects, landscape partnerships, and stakeholder agreements. Much of the landscape efforts have focused on providing buffer areas around installations to provide critical habitat for listed species while maintaining areas sufficient for military training missions on specific installations. Current focus areas for implementation of REPI approaches include increasing REPI funding, promoting REPI policy for DoD installations, investing in large landscape partnerships, exploring off-installation regulatory solutions and accelerating buffer creation and enhanced results.

Landscape level partners often include the DoD, NRCS, USFWS, state agencies, and nongovernmental organizations. A collaboration between the U.S. Departments of Defense, Agriculture, and Interior formed the Sentinel Landscape Partnerships in 2013. The purpose of this collaboration was to promote natural resources sustainability through mutually beneficial programs to preserve, enhance and protect habitat and working lands subjected to military mission activities. 
The first Sentinel Landscapes project was undertaken at Joint Base Lewis-McChord (JBLM). JBLM is an important power projection platform for the U.S. Army. Military activities include training missions for operational airlift of personnel, vehicles, supplies and materials to areas of conflict. JBLM is also home to large areas of prairie habitat that is habitat for ESA listed or candidate species, including the Taylor's Checkerspot Butterfly (Euphydryas editha taylori), Streaked Horned Lark (Eremophila alpestris strigata), and the Mazama Pocket Gopher (Thomomys mazama).

The JBLM Sentinel Landscapes partnership is working to expand protection strategies on and off the installation through endowments, stewardship demonstration projects, and regulatory flexibility for private landowners and DoD. Expanded outreach and education, plus creation of a regulatory framework for credits on and off the installation that improve baseline conditions for these species as well as providing better flexibility for on-base training missions.

Another example of cooperative conservation that serves to sustain military activity occurs in the Southeastern U.S. where multiple parties have committed to the restoration of Longleaf Pine (Pinus palustris) habitat. The Longleaf Pine Restoration Initiative created a comprehensive management plan through a Regional Working Group representing 22 organizations. Implementation of the comprehensive management plan is executed through collaborations between DoD, Agriculture, and Interior. A Longleaf Pine Stewardship fund was developed and is administered by the National Fish and Wildlife Foundation (NFWF).

As mentioned, a regulatory solution for conservation planning of the Red-cockaded Woodpecker on Camp Lejeune through Section 7(a)(1) process has been successful in promoting species recovery while permitting ongoing mission activities on the installation. A similar approach is being taken with the Gopher Tortoise (Gopherus polyphemus), a candidate species found throughout the Southeastern U.S. As of the date of the workshop, the DoD is working with the USFWS to establish credit for protection of this species on off-base conservation areas, including areas identified for Longleaf Pine habitat restoration. A credit system would permit DoD installations to maintain off-base habitat suitable for sustaining populations of listed species while permitting on-base training activities. The goal is to proactively promote conservation of listed species and preclude the need to list candidate species under ESA. (Editor's Note: on March 24, 2017, the Gopher Tortoise Strategy was signed by the parties and came into effect).

Authority to implement the REPI approach as described is found in 10 U.S. Code $\S 2684 \mathrm{a}$. Eligible partnerships include state or subdivision of a state (e.g., county), a private entity with a stated principle of conservation and natural resources preservation, or a 501(c)(3) non-profit organization or a for-profit conservation organization. Other authorities include the Sikes Act, conservation banking (under ESA) and mitigation banking (under the Clean Water Act).

NOAA and Federally Listed Species (Ron Salz, NOAA National Marine Fisheries, Office of Protected Species, and Chris Yates, NOAA West Coast Region). The National Oceanic and Atmospheric Administration (NOAA), National Marine Fisheries Service (NMFS) Office of Protected Resources (OPR) is working to accommodate future Section 7(a)(1) conservation planning. Currently, there over 150 ESA listed species in NMFS jurisdiction including marine and anadromous fish (salmon, sturgeon, grouper, sharks, and others), marine mammals (dolphins, whales, sea lions, seals), invertebrates (coral, abalone), reptiles (sea turtles, 
sea snakes) and one plant species. There is an agency-wide effort (Species in the Spotlight) to stabilize populations of eight ESA-listed species that are most at risk of extinction: Atlantic Salmon (Salmo salar), Central California Coast Coho Salmon (Oncorhynchus kisutch), Cook Inlet Beluga Whale (Delphinapterus leucas), Hawaiian Monk Seal (Neomonchus schauinslandi), Pacific Leatherback Sea Turtle (Dermochelys coriacea), Sacramento River Chinook Salmon (Oncorhynchus tshawytscha), Southern Resident Killer Whale (Orcinus orca), and White Abalone (Haliotis sorenseni). The NMFS is developing Section 7(a)(1) guidance documents and exploring incentives for federal agencies to engage in Section 7(a)(1) consultations. The agency's approach to Section 7(a)(1) implementation includes cultivating federal agency collaborators, tracking progress, providing recognition for successful conservation programs and targeted actions that have had a beneficial impact. Some examples of federal agencies that the NMFS OPR is working collaboratively with for ESA-listed species conservation include the NMFS Office of Habitat Conservation (Community-based Restoration Program), the National Ocean Service's Office of National Marine Sanctuaries (Partnerships for Transboundary Protection Program), and the USACE Engineering with Nature (EWN) Program. EWN is the intentional alignment of natural and engineering processes to deliver environmental and social benefits. Anticipated beneficial outcomes of Section 7(a)(1) consultation on EWN include identifying project designs that benefit NMFS species and/or habitat early in the planning process, creating sustainable projects in areas subjected to climate change, promoting interagency cooperation and reducing conflict, and increasing efficiency and certainty of the regulatory process. For more information, contact the NMFS Office of Protected Species (www.nmfs.noaa.gov/pr $)$, Species in the Spotlight (http://www.nmfs.noaa.gov/stories/2015/05/05_14_15species in the spotlight.html), and the NMFS West Coast Regional Office (http://www.westcoast.fisheries.noaa.gov).

The NOAA NMFS West Coast Region covers Washington, Oregon, Idaho, and California. The agency is in charge of implementing the ESA, Magnusson Act, and Marine Mammal Protection Act. A primary requirement is to manage federal fisheries and conserve listed species, marine mammals, and their habitats. Most ESA listed species include salmon, steelhead, sea turtles, abalone, Green Sturgeon (Acipenser medirostris), Eulachon (Thaleichthys pacificus), and marine mammals. In terms of regulatory jurisdiction with the USACE and DoD, efforts generally focus on anadromous fish, marine species including turtles and whales, and coastal habitats. In order to initiate a Section 7(a)(1) conservation planning collaboration, a clear understanding of incentives and assurances must be stated for all parties involved. There is a need for clarity as to why agencies should participate in Section 7(a)(1), simply increasing baseline data for target species is insufficient for conservation planning. Successful examples of Section 7(a)(1) planning implementation often occur after considerable tension and/or traumatic events. In the future, proactive efforts are needed to prevent such situations before they arise. In particular, the DoD needs to know why it is in their self-interest to implement conservation planning. Good starting points for discussion that may lead to Section 7(a)(1) conservation planning includes recovery plans, Section 7(a)(2) recommendations and BMPs, goals and objectives of other programs (e.g., restoration efforts within USACE), West Coast Region Recovery Integration guidance plans, safe harbor agreements, and DoD Integrated Natural Resource Management Plans (INRMPs). Several examples in the West Coast Region include conservation for threatened and endangered anadromous fish (e.g., Southern California Steelhead; Oncorhynchus mykiss) in South-central and Southern California. Numerous collaboration with DoD facilities in the San Diego Bay, Naval Weapons Station, Marine Corps Base Camp Pendleton, San Nicholas and San Clemente 
Islands, and Vandenberg Air Force Base have resulted in good outcomes for the facilities and targeted species. A strong partnership with the U.S. Navy is currently implementing research on the White Abalone through a recently signed agreement. Research efforts will include population estimates and habitat surveys, development of methods for outplanting, and fine scale habitat use through acoustic tracking monitoring.

\section{SPECIES-SPECIFIC PRESENTATIONS AND FACILITATED DISCUSSION}

\section{Least Bell's Vireo (LBVI): Abundance, Distribution, and Status Overview (Peter Beck, USFWS, Carlsbad Fish and Wildlife Office). The LBVI (Vireo bellii pusillus) is a} small, gray passerine endemic to southern California and the Baja Peninsula of Mexico. This subspecies is a riparian obligate that utilizes habitats dominated by willow (Salix spp.), cottonwood (Populus spp.) and sycamore (Platanus occidentalis), but it can tolerate a broad range of habitat and riparian systems subjected to a variety of hydrological conditions. During the $19^{\text {th }}$ century, this subspecies was considered common, but habitat loss and degradation has significantly reduced the population. Agriculture, urban development and flood control/channelization of river systems are the primary causes of habitat loss. The creation of dams, flow diversions, and groundwater pumping has made riparian systems in the southwest untenable for many native riparian trees. Invasive species, such as Saltceder (Tamarix spp.) and Giant Reed (Arundo donax), have degraded many riparian habitats. Moreover, this bird is susceptible to brood parasitism by the Brown-headed Cowbird (Molothrus ater), a species that has invaded the southwest from the Midwestern region of the United States. The LBVI was listed as endangered under the ESA in 1986.

Prior management actions have focused on limiting habitat loss and degradation, restoring or enhance existing habitat, control of invasive species, and supporting research on population ecology and effects of management actions. Management actions have successfully increased population from a low of 300 pairs at the time of listing, to about 2,500 to 3,000 pairs today. Approximately $85 \%$ of the population is located in Southern California, in San Diego and Western Riverside counties, the remaining 15\% are found in Orange, San Bernardino, Los Angeles, and Ventura counties. The breeding population is concentrated in the Santa Ana River Watershed and Prado Basin, which includes Camp Pendleton, and the San Luis Rey River Basin. Distribution, abundance and population trends in Baja California remains unknown.

Current threats include ongoing habitat loss and degradation, with additional threats from reclamation of wastewater and climate change. A new invasive species, a beetle/fungi symbiotic complex, known as the polyphagous shot hole borer (Euwallacea spp.) is also causing loss of native trees and habitat in the region. Parasitism by the Brown-headed Cowbird continues to threaten the population. The recovery plan entails increasing overall population size, expanding geographic distribution, and managing threats. To down-list the species, eleven focal areas (San Diego to Santa Barbara) are to have stable populations supporting hundreds of breeding pairs, coupled with ongoing protection and management. To delist the species, three additional focal sites are being targeted (Salinas, San Joaquin, and Sacramento Valleys) for supporting stable populations, plus management goals that ensure no additional human intervention for population sustainability. However, this species is considered a conservation reliant species that will require 
ongoing management (e.g., invasive species control) for the indefinite future to secure the population for the long-term.

\section{Integration, Progress and Challenges to Regional ESA Section 7(a)(1) Conservation Planning: Least Bell's Vireo (LBVI) at Whittier Narrows and Prado Dam, Southern California. (Tom Keeney, USACE Los Angeles District). Virtually all} watershed basins in the Los Angeles area support some pairs of LBVI. The Whittier Narrows Dam Reservoir is located in Southern California and is part of the San Gabriel River Water Conservation System. The USACE Whittier Narrows Dam Reservoir Basin supports transportation, recreation and natural resources management, but unlike other Districts, much of the land has been leased out. Although the basin is designed for flood risk management, the USACE is also involved in water conservation and protection of riparian habitat. This basin has also been involved with dam Safety work, necessary since the Whittier Dam is broken and in need of repair. Modification of the system will include increasing height of existing levees, realignment of the channel as needed, and raising the dam embankment. Approximately 6 million residents will be impacted in Los Angeles if the dam fails. Repairing the dam to hold more water may change current elevations that are usually dry. Most habitat for the vireo is around $205 \mathrm{ft}$ above sea level. When the dam is repaired, some habitat areas may be inundated.

The Whittier Narrows Basin has been involved in Section 7(a)(1) conservation planning for the LBVI, the Coastal California Gnatcatcher (Polioptila californica), and the SWFL. The reservoir project manages several natural resource areas where primary habitat components for the vireo, gnatcatcher, and flycatcher have been identified. Habitat components for the gnatcatcher include over 500 acres with areas for foraging, nesting, rearing of young, intra-specific communication, roosting, dispersal, genetic exchange, and shelter. These are generally undeveloped areas that support chaparral, grassland and riparian habitats, proximal to sage scrub which is used for breeding and foraging. Primary habitat components for the vireo include mixed riparian habitat dominated by native willow, cottonwood and mulefat scrub (Baccharis salicifolia). In every basin since 2010, vireo populations have been increasing. Since 2014, the Whittier Narrows Basin has supported about 20 breeding territories for the vireo. Edges with tree/shrub habitat is considered essential for this species. Primary habitat components for the flycatcher include mixed willow riparian areas, willow-cottonwood areas, and mid-to-late successional vegetation at least $10-15$ years old and $>60 \%$ canopy cover. This species is known to use non-native trees, such as saltceder (Tamarix spp.); therefore, some areas with invasive trees are identified as primary habitat for this bird.

Numerous plans are in development for habitat restoration above and below State Road 60. If restoration takes place, it is believed that breeding areas for LBVI have the potential to double the current population. Plans to restore coastal sage habitat will likely increase habitat and population for the California Gnatcatcher as well. Future Section 7(a)(1) conservation planning will include the planned restoration efforts, plus continued surveys for vireos (nest monitoring, habitat utilization, color-banding of all birds) and gnatcatcher (presence/absence surveys), limited control of Brown-headed Cowbirds, and contending with homeless camps in the area.

Tidewater Goby: Abundance, Distribution and Science Overview. (Peter Beck, USFWS, Carlsbad Fish and Wildlife Office). The Tidewater Goby (Eucyclogobius 
newsberryi) is a small gray-brown translucent fish that inhabits coastal lagoons with brackish water. The fish can tolerate a wide range of salinities and may move through marine environments after a storm breaches the lagoons. This species is short-lived, usually less than one year. Reproduction can occur year-round, but generally peaks in May through July, sandy substrates are preferred for egg-laying. The fish ranges from San Diego to Del Norte counties and is distributed along most of the California coast. Recent research suggests that the southern most population in San Diego may be a distinct species. Many sites experience local extirpation and recolonization events that form a metapopulation, but limited by need for lagoons to be in close proximity. Within a locality, populations may fluctuate by several orders of magnitude during the year. At the time of listing, the species was found in only 48 of 87 original locations. However, recent surveys have found populations in 114 of 135 areas searched. Unsure if higher abundance due to improved survey methods or if the fish has repopulated previously extirpated lagoons. Habitat loss and degradation is the primary cause of population decline. Development along the coasts, including port and marina development and roads, bridges and housing may all negatively impact habitat. Hydrological modifications from dams, diversions, flood control, groundwater extraction, plus chemicals and sedimentation from agriculture will also degrade habitat. Non-native predators and extreme weather events (e.g., droughts and floods) will cause population declines. Current management actions include protecting and enhancing existing lagoons where this fish is found. Ongoing research is seeking to find solutions to current land use practices that negatively impact this fish. Efforts are also testing the possibility of implementing translocation actions under some circumstances. In addition, more effort is being made to inform the public about the tidewater goby and its current status in the region.

Tidewater Goby on Marine Corps Base (MCB) Camp Pendleton. (Sherri Sullivan, MCB Camp Pendleton). The format of this presentation is to provide an overview of the history of MCB Camp Pendleton, discuss management of threatened and endangered species on the installation, provide some examples of Section 7(a)(1) conservation planning efforts, and review some requirements of Section 7(a)(2) consultations. Camp Pendleton was established after World War II. The installation is a national leader in amphibious training for the military, but training expertise has grown and expanded over the years. There are multiple competing land-use issues on the installation, especially when dealing with TES. The Nature Conservancy has identified 34 hot-spots of diversity in North America, and Southern California is one of those areas. With high diversity also comes high numbers of TES. There are 18 listed species in the region and 11 on the installation (excluding plants). The region around Camp Pendleton has become increasingly urbanized and the installation acts like an island for many species. The installation uses the NEPA mandated Integrated Natural Resources Management Plan (INRMP) to address management of all TES. This effort represents a proactive approach to use Section 7(a)(1) conservation planning on the installation. A draft revision of the INRMP is currently in the process of being finalized.

Camp Pendleton allocates large amounts of funds and people towards the management and conservation of TES. The Environmental Conservation Division, Planning Division and Environmental Compliance Resource Management Division work to provide effective management of all species on the installation. The Planning Division work through the Section 7(a)(2) planning process, while the Resource Management Division work through the Section 7(a)(1) planning process. The installation generally relies on contract support to assist with 
ongoing monitoring efforts. Representatives in the divisions participate with working groups, recovery teams, and regulatory personnel.

Conservation planning detailed in the INRMP raises awareness of the regional diversity that is found on the installation. Current monitoring and research efforts are assessing the ecological function of estuaries, including the Santa Margarita River Estuary as part of a Section 7(a)(2) consultation. The effectiveness of the management efforts detailed in the INRMP is scored annually based on multiple criteria including (1) project implementation, (2) evaluation of TES and their habitats on the installation, (3) assessment of partnership effectiveness and collaboration in monitoring and management of natural resources, (4) internal assessment of team adequacy, and (5) integrity of ecosystems on the installation.

Examples of Section 7(a)(1) conservation planning on the installation include management of the California Least Tern (S. a. browni) and the Western Snowy Plover (Charadrius alexandrines nivosus). These birds occupy approximately 17 miles of beach habitat on the installation, and the breeding season extends for about five months in the spring and early summer. Time and location of breeding season conflicts with required amphibious training exercises. Current approach is derived from a 1995 Biological Opinion. Required management includes, (1) monitoring and management for both species, (2) effective vegetation control to enhance habitat, (3) seasonal fencing on three breeding areas, (4) protection of nesting pairs outside these areas, (5) conducting predator control, and (6) performing ecosystem monitoring on the coastal habitats. In 2013, the installation was able to reduce daytime monitoring efforts and determined optimal vegetation height for both species (between $5-10 \%$ cover). Research also found that previous estimates of fledgling success were too low, this should help the installation to eventually reach recovery goals. The installation also recently ended raptor control efforts. Lethal control was ended and raptor removal was ineffective as birds would return.

The Pacific Pocket Mouse (Perognathus longimembris) was thought to be extinct until rediscovered in 1993. A small population exists on Camp Pendleton near some firing ranges. There is a current proactive management effort under Section 7(a)(1) with the USFWS to protect this species. Ongoing efforts are trying to establish populations outside the installation to enhance population sustainability. Research is also ongoing to evaluate current survey methods and scat analyses to determine foraging and nutritional needs for this species.

The Tidewater Goby has been found on all eight estuaries on Camp Pendleton. The Santa Margarita Estuary is open to the bay and this fish is only found sporadically (not found in this estuary since 2001). The prior Section 7(a)(2) consultation for estuaries mentioned earlier is supporting efforts to survey and monitor for the Tidewater Goby. Ongoing efforts have generally surveyed for this species every three years. Recently, 127 fish were captured and moved to Lake O'Neill. If this effort to transplant this species to other areas is successful, then additional efforts may be planned. In addition, some fish may be captured and moved to aquariums in the area to protect the fish from future storms. After storm events, aquarium fish may be moved to other estuaries or lakes with little or no known predation risks. 


\section{OPEN DISCUSSION: Part I - Conservation Planning and Action Agencies}

The open discussion sessions focused on differentiating Section 7(a)(1) and 7(a)(2) consultations for conservation planning and to detail why Section 7(a)(1) is preferable. The discussions identify problems in funding mechanisms between the approaches and confusion as to how best initiate a Section 7(a)(1) conservation effort. These discussions also relate experiences with currently listed species and potential problems or opportunities with candidate species and/or atrisk-species that may become listed in the future. The following is a summary of the main points:

\section{USFWS and Action Agencies}

- Follow the money - need specific funding mechanism to direct funds to Section 7(a)(1) conservation efforts.

- More flexibility in Section 7(a)(1); does not work the same as Section 7(a)(2).

- NEPA documents involve conservation planning and tend to follow the Section 7(a)(1) approach.

- Separate sections for conservation planning lie at the intersection of the consultation process with USFWS.

- Integrated process early on permits better cohesion between Section 7(a)(1) and 7(a)(2) groups working on conservation planning within the same organization or installation.

- There is a need for more training for future Section 7(a)(1) efforts; need to initiate change in culture among federal/state agencies; need for paradigm shift for moving forward at a top-down approach.

- USACE ERDC Technical Reports available on Section 7(a)(1) conservation planning for Lower Mississippi and ESA listed species on DoD lands nationwide.

- Fat Pocketbook Mussel invasion of Lower Mississippi River a good thing; Section 7(a)(1) conservation planning effort was able to include multiple species into planning effort; USFWS can provide credit for success; success is a collective benefit for all agencies involved; only works when/if the USFWS is willing to recognize and give credit to action agencies; USFWS has made mistakes in past; need a culture shift in USFWS.

- What can USFWS do to facilitate cultural shift in other action agencies? Could provide mandated guidance documents for Section 7(a)(1) planning efforts; "More carrot, less stick" approach; USFWS needs to build trust and collaboration; There is a need to come to the table with assurances and incentives for action agencies to participate in Section 7(a)(1) conservation planning.

- There will have to be compromises for all agencies involved; USFWS will need assurances from action agencies that they will follow through on conservation efforts; action agencies need to procure funding for Section 7(a)(1) actions and mitigation requirements.

- Real collaborations go both ways, all parties involved need to keep promises on actions and funding, incentives and assurances. 
- Need to acknowledge challenges of Section 7(a)(1) conservation efforts: (1) business line actions, (2) budgetary issues, (3) knowledge gaps, (4) risk management and uncertainty, (5) agreed upon definition of what success will look like, (6) what does compliance mean and when has it been achieved, and (7) how to meet goals while meeting mission requirements for all agencies involved.

\section{DoD Efforts and Challenges}

- DoD budgetary process not fully aligned with Section 7(a)(1) process at this moment; other agencies also in process of shifting priorities and approaches (e.g., USDA-NRCS and WLFW program with private landowners. This is still a work in progress, but efforts are increasing).

- DoD needs help to meet goals for conservation and mission success; starts with new model of success - not just compliance; not trying to game the system, but trying to get the system to fit the game.

- Problem: lots of people in the chain of command before reaching people who can change policy. By the time efforts get to upper policy makers, the ideas can become political and deviates away from the intended goal of implementing knowledge-based management for listed species.

- Natural resources management takes time, patience, funds and collaboration; change will not happen overnight (e.g., Marine Corps RASP efforts required 2+ years of talks before successful management efforts with Red-cockaded Woodpecker could take place).

- In addition to defining success, there is a need to show success when it has occurred. It is often difficult to show united success among collaborating partners when target species has expanded range or when recovery goals for installation/region have been met. Do not hesitate to use media/reports/interviews and social media platforms when appropriate and authorized.

\section{Conservation for Candidate and At-Risk-Species}

- Regionally identified candidate and at-risk-species provide opportunities for proactive approach to avoid future conflicts. This is very similar to Section 7(a)(1) efforts.

- Can justify by working collaboratively with other stakeholders to prevent such species from becoming listed. This enhances flexibility with USFWS and protects against future mission restrictions.

- If species does become listed, then you already have a plan in place that conforms to the Section 7(a)(1) conservation planning process and that will cover all compliance contingencies. These efforts will be funded without any regulatory pressure or need to comply with Biological Opinions. 


\section{PART II - Individual Species Issues}

- The LBVI is a good species to show how Section 7(a)(1) is useful for conservation planning.

- Looking for good ideas to move forward. Ideas need to define current problems, opportunities for collaboration, impediments and challenges, and identify knowledge and science needs.

- USACE and DoD have lands that could be rehabilitated into suitable LBVI habitat; funding sources are available, need to know how to tap into such funding; need more guidance materials; approach agency policy makers, show examples and justify risk, and show where opportunities exist to test management actions.

- An exercise was implemented to identify opportunities, potential impediments, challenges, and science and information needs for LBVI. This is summarized in Table 1.

\begin{tabular}{|c|c|c|c|}
\hline Opportunities & \begin{tabular}{|l|} 
Potential \\
Impediments and \\
Challenges
\end{tabular} & $\begin{array}{l}\text { Science and Information } \\
\text { Needs }\end{array}$ & Communications \\
\hline $\begin{array}{l}\text { USACE reservoir basins in } \\
\text { the Los Angeles District }\end{array}$ & $\begin{array}{l}\begin{array}{l}\text { Getting buy-in from key } \\
\text { people }\end{array} \\
\text { plate }\end{array}$ & $\begin{array}{l}\text { Testing management actions } \\
\text { via effectiveness monitoring }\end{array}$ & Get success stories out \\
\hline $\begin{array}{l}\text { Potential funding to assist } \\
7(a)(1) \text { efforts from TEST and } \\
\text { DoD REPI }\end{array}$ & $\begin{array}{l}\text { Need to get away from } \\
\text { idea that surveys are } \\
\text { only to support ESA } \\
\text { Section } 7\end{array}$ & $\begin{array}{l}\text { Monitoring to measure effects } \\
\text { of actions on both mission } \\
\text { and species }\end{array}$ & $\begin{array}{l}\text { All involved need to brief } \\
\text { actions and needs } \\
\text { upward in management } \\
\text { chain }\end{array}$ \\
\hline $\begin{array}{l}\text { Develop guidance with } \\
\text { examples for success }\end{array}$ & & $\begin{array}{l}\text { How do we best rehabilitate } \\
\text { habitat for LBVI and other } \\
\text { riparian-dependent spp. }\end{array}$ & $\begin{array}{l}\text { Need to reach out to } \\
\text { California Dept. of Fish } \\
\text { and Wildlife }\end{array}$ \\
\hline $\begin{array}{l}\text { USGS is providing science } \\
\text { support for monitoring - } \\
\text { others could follow example }\end{array}$ & & $\begin{array}{l}\text { Use habitat-based models to } \\
\text { plan for a mosaic of habitats } \\
\text { for various spp. }\end{array}$ & \\
\hline $\begin{array}{l}\text { LBVI can be a riparian } \\
\text { indicator species }\end{array}$ & & $\begin{array}{l}\text { How to undergo landscape } \\
\text { conservation designs }\end{array}$ & \\
\hline $\begin{array}{l}\text { Need clear information of } \\
\text { rangewide threats so they can } \\
\text { be addressed }\end{array}$ & & $\begin{array}{l}\text { Assess impacts of climate } \\
\text { change }\end{array}$ & \\
\hline $\begin{array}{l}\text { Better integrate } \\
\text { training/operations into } \\
\text { conservation planning }\end{array}$ & & $\begin{array}{l}\text { Better knowledge of impacts } \\
\text { by Shothole-borer }\end{array}$ & \\
\hline $\begin{array}{l}\text { USFWS seeking expert } \\
\text { opinion/stakeholder input on } \\
\text { species action plans }\end{array}$ & & $\begin{array}{l}\text { Update recovery plan or } \\
\text { strategies with tiered } \\
\text { checklist/action plan by } \\
\text { watershed } \\
\end{array}$ & \\
\hline $\begin{array}{l}\text { Define targets and benefits of } \\
\text { reaching each }\end{array}$ & & $\begin{array}{l}\text { Need coordinated landscape } \\
\text { scale monitoring, surveys, } \\
\text { and data management }\end{array}$ & \\
\hline \multicolumn{4}{|l|}{$\begin{array}{l}\text { Consider flexible and } \\
\text { defensible "take" statements }\end{array}$} \\
\hline \multicolumn{4}{|l|}{$\begin{array}{l}\text { Export Camp Pendleton's } \\
\text { "model” of success }\end{array}$} \\
\hline $\begin{array}{l}\text { Action agencies need to } \\
\text { prioritize needs from USFWS }\end{array}$ & & & \\
\hline
\end{tabular}




\section{MCB Camp Pendleton}

- Funded giant cane removal, mission impacts on LBVI by USGS, impacts of fire, reduced monitoring efforts to increase research studies to determine what management actions work and what does not, Increase efficiency of available funds spent.

- Useful to have access to LBVI population data. With additional support from private landowners, have study area access and funding; can investigate response of LBVI to cowbird management, fire, drought, flood and habitat rehabilitation.

- Ongoing efforts to remove 1,300 acres of giant cane. Need to replace with native riparian species to enhance habitat for LBVI and Southwestern Willow Flycatcher.

- Looking for additional opportunities, not all areas need to support TES. Using habitat models on landscape to identify best places for habitat rehabilitation for some species. Be more strategic and avoid piecemeal approaches.

- Using LBVI as representative species for riparian habitats. Strategically looking at species as indicator for impacts of habitat changes, climate change, cowbird management, effects of invasive species, etc.

- Good collaboration with USFWS, but difficult to examine impacts of management and training actions. Know that management actions have been beneficial but have not shown benefits in future plan development, INRMPS, etc.

- With limits of restrictions due to collaborations, still not sure of impacts of training exercises on species. If impacts of mission actions are addressed, how can actions alter training to meet needs of target species? Conservation efforts come down to opportunities. If impacts of missions are not known, then it also becomes difficult to assess impacts of any beneficial management action.

- Need to assess operation threats. Conservation plans often don't address operational issues with TES management.

- Historically, science does the work in collaboration with management efforts, but there is little communication of how the program impacts target species and other impacts to operations. Efforts don't move up the chain to upper management (NRCS has better format for internal and external communication).

- Training rotations and overall training operations have increased on MCB Camp Pendleton. Perception of TES are increasing from monitoring efforts. However, impacts on military mission need to be addressed.

- USFWS not great at finalizing conservation plans and updating 5-year reviews.

- Currently working to prioritize action plans for target species. Seeking expert solicitation for LBVI plan and obtaining feedback from stakeholders (what are the needs and what else can be done to enhance recovery?).

- MCB Camp Pendleton has done all it can for the LBVI. Density has been maximized on current habitat within installation boundaries. If species can be recovered, what more can the installation do? How can the installation do more to meet recovery goals? How much more funds can be spent on the species by the installation? 
- MCB Camp Pendleton is collaborating with USDA-NRCS to manage over 100,000 acres of easements to promote LBVI populations outside of installation boundaries.

- As for incentives, a decrease in restrictions for meeting LBVI population recovery goals will be limited because of restrictions for other species (e.g., SWFL). There are no easy solutions to get LBVI off list, this will require range-wide effort.

- Multi-species conservation planning in southeast (e.g., Lower Mississippi River) may serve as good example for MCB Camp Pendleton to move forward.

\section{Translate Success for DoD}

- $\mathrm{RCW}$ population recovery serves as example of success from sustained commitment by all agencies. Six out of thirteen populations restored and another two are on trajectory to meet recovery goals

- The DoD often uses the language of "hitting targets" to clearly define what specific recovery targets are needed for recovery on DoD lands, these define criteria for determining when target has been met.

- Example: With 50 active RCW clusters on installation, military was allowed to remove restrictions for training operations in specific areas. With 100 active clusters, additional restrictions were removed. With verified recovery, all restrictions were removed.

- Under this arrangement, military was permitted to remove active RCW clusters during training as long as removal did not affect baseline target for active clusters.

- With signed agreement and commitments that clearly state recovery goals, USFWS agreed to remove restrictions; currently, the installation has nearly 100 active RCW clusters above recovery goals.

- Now, looking at range-wide RCW status, next recommendation could suggest delisting.

- Section 7(a)(1) conservation plans should address all needs; needs for the species, needs for USFWS, and needs for action agency.

- Need scientifically-based data/assessment to determine specific recovery goals, meeting target, setting goals, meeting target, etc. until recovery is achieved. This sets the overall benefit for the species as determined by measurable increase in population viability.

- This approach could help with installations working on LBVI populations by providing incentive based plans (e.g., installation could attract more breeding pairs with incentives that they could remove pairs during training if necessary), as long as baseline population remains essentially unchanged.

- Need to commit to monitoring to ensure goals are being met. Installations have to demonstrate transparent methods and data for independent assessment of success. Also, they need to clearly state incentives that benefit species.

- The DoD needs to be clear about needs and requirements important to mission success. They need to know what to ask for, RASP for RCWs is a good example of how the DoD can work to benefit target species while meeting mission operations and requirements. 
- The Lower Mississippi River Conservation Plan worked due to lots of luck. Not all efforts will go as well, initiated after jeopardy decisions that are still in place. Beneficial management actions proceeded because USFWS couldn't prove or quantify “take." They eventually defined take as loss of secondary channels, with actions to restore such channels, recovery of target species ensued, restrictions were removed and compliance upheld.

\section{Conflicts and miscommunication with USFWS}

- An example is mentioned about California Least Terns where accidental increased take of birds occurred. Despite ongoing efforts by installation to benefit species, USFWS would not agree to change take levels.

- As population of target species increases, take restrictions should decrease. In the past, the Marine Corps did not formally request increase in take of terns and they cannot ask for increase after the fact. They need be clear about goals and targets early during conservation planning with USFWS.

- USFWS made serious mistakes when implementing conservation efforts for California Tiger Salamander (Ambystoma califoriense). This resulted in no cooperation from private landowners. The agency needs to learn to listen and work collaboratively for benefit of target species.

\section{Multi-state Conservation Planning}

- Even reactive conservation planning efforts can be beneficial if all stakeholders participate in efforts. Commitment by upper management in action agencies, work with private landowners and ranchers (e.g., BLM has been successful with this type of effort), develop multi-species planning to leverage limited funds for the most benefit, work with military installations and land managers outside installation boundaries is needed.

- Many private landowners do not impact riparian habitats on their property because of permits and use restrictions for riparian zones. Therefore, conservation planning could be designed at the watershed scale.

- Section 7(a)(1) efforts to proactively benefit populations of the gopher tortoise (Gopherus polyphemus) include multiple state agencies, multiple federal agencies, power and utilitiy corporations, non-governmental organizations and private landowners. Commitments include efforts by WLFW and Long-leaf Pine Initiative administered by the National Fish and Wildlife Foundation (NFWF). Sometimes, private landowners may be more willing to work with a non-governmental organization.

- Gopher tortoise tied to long-leaf pine habitat funds are going towards ecosystem restoration that will benefit multiple species. A $\$ 500 \mathrm{k}$ investment has turned into a $\$ 10$ million restoration effort.

- In the Southwest, the need to pool efforts for riparian restoration, invasive species control, and cowbird control to target LBVI, SWFL, tiger salamander, etc. exist. It should be possible to duplicate the success observed for the Lower Mississippi and the RASP effort for RCWs. 


\section{Richard Fischer - five-point summary}

1) Address stressors (e.g., climate change). How do we address in INRMPs? Impacts on LBVI? Polyphagous shot-hole borer presents a new challenge, how to manage for impacts? Also, water diversions have had significant impacts in the Southwest, how to meet water resources needs while managing and rehabilitating riparian areas?

2) Need to work proactively and collaboratively with USFWS to address priority species and address stressors.

3) Identify stressors at watershed level.

4) The USFWS needs to update guidance for conservation planning efforts; develop stepdown strategy for target species recovery by action agency that is appropriate and involves all stakeholders.

5) Interagency collaborations for incorporating landscape level designs for range-wide conservation efforts are needed. State and regional joint ventures work with landscape level conservation plans, plus the Landscape Conservation Cooperatives (President Obama initiative) are using LCC grants to fund range-wide conservation and post-listing monitoring efforts for the Interior Least Terns, this could possibly work with other species as well. Different federal agencies are leading the LCC in different regions. Agencies include USFWS, National Park Service, Bureau of Land Management, etc. 


\section{PART III - Final Discussion}

\section{Tidewater Goby Issues}

- Translocation is a possibility for the southern population of this species (southern population may be distinct species) on MCB Camp Pendleton. The installation would benefit if population had more redundancy in the region

- Private lands not really an issue because of the estuaries and lagoons where this species resides.

- Only three estuaries of the southern species located above Camp Pendleton, another single population is located south of the installation.

- May need to focus on threats since this species has such a restricted range.

- People are concerned about local extirpations, populations exhibit significant year-to-year flux and it is difficult to determine long-term viability for local populations over time.

- An exercise also was implemented to identify opportunities, potential impediments, challenges, and science and information needs for the Tidewater Goby. This is summarized in Table 2.

\begin{tabular}{||l|l||l||l||}
\hline \multicolumn{3}{|l|}{ Table 2. Results of focused discussion on Tidewater Goby. } \\
\hline \hline & $\begin{array}{l}\text { Potential } \\
\text { Impediments and } \\
\text { Opportunities }\end{array}$ & $\begin{array}{l}\text { Science and Information } \\
\text { Needs }\end{array}$ & Communications \\
\hline $\begin{array}{l}\text { Conservation actions to } \\
\text { increase species baseline }\end{array}$ & $\begin{array}{l}\text { Sufficient opportunities } \\
\text { to provide for population } \\
\text { redundancy? }\end{array}$ & $\begin{array}{l}\text { Science input for } \\
\text { translocation methods }\end{array}$ & \\
\hline $\begin{array}{l}\text { Public partnership(s) to be } \\
\text { receiving entity for possible } \\
\text { translocations }\end{array}$ & $\begin{array}{l}\text { Need for redundancy } \\
\text { both on and off MCB } \\
\text { Camp Pendleton }\end{array}$ & $\begin{array}{l}\text { Captive populations as } \\
\text { sources for translocation }\end{array}$ & \\
\hline & $\begin{array}{l}\text { Improve habitat at } \\
\text { potential receiving sites } \\
\text { in S. Orange Co. and N. } \\
\text { San Diego Co. }\end{array}$ & & \\
\hline & $\begin{array}{l}\text { Managing threats to } \\
\text { populations }\end{array}$ & & \\
\hline
\end{tabular}

\section{More Issues about Conservation Planning}

- Even reactive conservation planning efforts can be beneficial if all stakeholders participate in efforts. The need for commitment by upper management in action agencies, work with private landowners and ranchers (e.g., BLM has been successful with this type of effort), develop multi-species planning to leverage limited funds for the most benefit, and work with military installations and land managers outside installation boundaries exists.

- USFWS: multiple entities working on development of guidance documents for Section $7(a)(1)$ conservation planning. This is a piece-meal effort by different districts and regions. 
- Conservation planning guidance focused on specific components that are fundamental to the process and should be common to all such efforts. Region 5 has policy and guidance documents to share. This will be distributed to workshop attendees. Looking for flexibility and innovation in future conservation planning.

- Conservation planning needs to fit agency authority and landscape level, range-wide planning is preferable. Planning needs to be comprehensive, multi-species, and under action agency authority. Consult with local USFWS to start process.

- Many USFWS offices are swamped with work. Too many species are severely imperiled and the list of candidate and at-risk species is growing exponentially. Consultation efforts are growing exponentially and many offices do not have staff to complete jobs.

- Talk of potentially having to 'give up' on some species, simply no time, resources or funding to save all listed species.

- Challenge to deal with circumstances currently facing with limited resources.

- Need better, more realistic business model to be effective.

- Some existing examples of conservation planning by USFWS and other agencies, fit under Section 7(a)(1) process, but are not identified as such. USFWS has many good plans available, but these are not referenced as Section 7(a)(1) plans.

- Framework for Section 7(a)(1) planning in USFWS Southeast Region 4 is available, however, not all policy issues are addressed. For the framework attached to the integrated processing report with focus on RCW conservation efforts and Section 7(a)(1) conservation planning in the Lower Mississippi River, go to the USFWS southeast website to download the conservation plan for Lower Mississippi River (Cadillac of all existing Section 7(a)(1) plans). Other available plans for single species (e.g., Interior Least Tern) are much simpler.

- Usually, Section 7(a)(2) consultations are often initiated in isolation without regard to the rest of the ESA; the single species approach is used $99 \%$ of time.

- Don't get hung up on different Section 7 consultations; take advantage of opportunities for agencies to use appropriate context of ESA to procure more flexibility and control in daily operations. Develop support for conservation success and meet the compliance and ethical responsibilities of the action agency. The approach should be more programmatic rather than reactive.

- The USFWS, historically and institutionally, did not implement ESA planning to include incentives for action agencies, or for agencies to work collaboratively under Section 7. The USFWS must work to provide incentives for action agency participation in the conservation effort.

- No matter what happens, or what planning process is used, the need to record and receive credit for all that is being done and that has been done needs to occur. Keep positive about efforts and work proactively to reduce requirement of consultation.

- The DoD wants to free up restrictions to better meet mission requirements, but wants to do so through demonstrable recovery efforts. This needs to be publicized as a recovery that works. 


\section{USFWS New Mitigation Policy}

- A new mitigation policy has just been published by the USFWS (November 2016). This mitigation policy will work during the Section 7(a)(1) consultation process.

- The USFWS mitigation policy details how to deal with mitigation efforts now and in the future, every new project will now be required to have net conservation benefit. It is recommended that strategic and landscape level planning accommodates new policy directives.

- Misconception that mitigation is not needed for Section 7(a)(1) conservation planning, this is based on a misinterpretation of mitigation policy development back in 1981 . Mitigation issues are not linked to ESA, but this does not mean that mitigation is not applicable and cannot violate net benefit rule. Therefore, mitigation will be necessary in Section 7(a)(1) planning efforts.

- What will the USFWS be able to require? When/where can they require mitigation? Issue not completely clear, still seeking guidance and clarification.

- For the USFWS authority to require mitigation under Section 7(a)(2), consultation has been long understood. However, this is not the case for Section 7(a)(1) planning, language states that "shall" in reference to mitigation, but under Section 7(a)(1) planning, this has been interpreted as "you don't have to." This interpretation will change under new policy.

- The Mitigation requirement will soon be the new status quo. Three levels of mitigation to be addressed include, avoidance, minimization, and compensation to offset negative impacts during projects. This standard will be for net benefit, with no net loss, $39 \%$ of all habitat lost to development has occurred since prior mitigation policy was enacted. The new policy means to change this outcome.

- Every policy to be reviewed and will have mitigation considered if the need is apparent. Existing presidential memo and Department of Interior, USFWS policy supports this view of the necessity for mitigation.

- Presidential memo directs all agencies, including DoD, to mitigate for all negative impacts moving forward by including mitigation options in all Section 7(a)(2) and Section 7(a)(1) consultations. Projects should never be in jeopardy.

\section{Candidate and At-Rick-Species}

- Discussion covers issues with species of conservation concern, but only for those that are not yet listed under ESA: species include monarch butterfly (Danaus plexippus), Tricolored Blackbirds, and numerous species of bats.

- Monarch butterflies cross state lines and will require collaboration of private landowners. Tricolored blackbirds declined 75\% from an estimate of 400,000 to 140,000 individuals in Region 6, these are the highest potential for listing under ESA in region (also concern for U.S. Navy in the region. 
- Species that impact training on DoD installations are receiving the most attention, species noted in NEPA documents are also important and are receiving significant attention.

- Listing of the Western Pond Turtle (Actinemys marmorata) and the Western Spadefoot Toad (Spea hammondii) could have significant impact on training operations on MCB Camp Pendleton.

- The Bog Turtle (Glyptemys muhlenbergii) is also a potential future problem in Eastern United States.

SUMMARY: The ERDC, the USFWS, and the American Bird Conservancy, organized a workshop on 6-7 December 2016, at U.S. Marine Corps Base Camp Pendleton in Southern California. The purpose of the workshop was to bring multiple federal and non-governmental land managers together to discuss the value of Conservation Planning under the ESA Section 7(a)(1) process. This process can provide cost-savings, more flexibility in meeting mission requirements, and provides the best outcome for listed species. The process also promotes proactive actions on sensitive and rare species that may become listed in the future. Currently, most federal agencies and the DoD use the ESA Section 7(a)(2) process. This process is largely employed to avoid jeopardy situations under ESA. This process is costly, inflexible and is not designed to improve species' baselines. Presenters in the workshop provided examples of successful application of Section 7(a)(1) Conservation Planning efforts in the USACE South Pacific Division and elsewhere in the United States. Open discussion periods were held to identify problems and conflicts with management and conservation of listed species. Conflict resolution and opportunities to implement Section 7(a)(1) conservation planning efforts were discussed and summarized.

ACKNOWLEDGEMENTS: Information presented in this TN was derived from input by numerous attendees from the USFWS, USGS, National Oceanic and Atmospheric Administration, NMFS, USDA, NRCS, the USACE, the Los Angeles District, the ERDC, and numerous DoD installations, including U.S. Marine Corps Base Camp Pendleton and Barstow, U.S. Navy, San Celmente Island, Naval Base Coronado, Naval Facilities Southwest, Naval Weapons Station Seal Beach, among others. Additional contributions were provided by nongovernmental organizations including Tierra Data, Inc., American Bird Conservancy, and RECON Environmental, Inc. We are grateful to Mr. Bill Berry, U.S. Marine Corps Base Camp Pendleton, for hosting the workshop and to Aimee Roberson, American Bird Conservancy, for facilitating a discussion session during the workshop. Numerous presenters provided external reviews and suggested edits of their summarized information, and internal reviews were provided by Mr. Darrell Evans (ERDC-EL) and Dr. Nathan Beane (ERDC-EL).

POINTS OF CONTACT: For additional information concerning the Dredging Operations Environmental Research (DOER) Program and Threatened and Endangered Species Team (TEST), contact Dr. Michael P. Guilfoyle (601)-634-3432, Michael.P.Guilfoyle@usace.army.mil), Richard.A.Fischer $\quad$ (502)-454-4658, Richard.A.Fischer@erdc.dren.mil) or the manager of the Dredging and Environmental Research Program, Dr. Todd S. Bridges (601)-634-3626, Todd.S.Bridges@usace.army.mil. This TN should be cited as follows: 
Guilfoyle, M. P., R. A. Fischer, and J. F. Jung. 2019. "Summary of Threatened and Endangered Species Team Workshop: ESA Section 7(A)(1) Conservation Planning in the South Pacific Division," DOER Technical Notes Collection (ERDC/TN DOER-E43), U.S. Army Engineer Research and Development Center, Vicksburg, MS. www.doer.el.erdc.dren.mil.

\section{REFERENCES}

Florida Key Deer v. Stickney, 864 F. Supp. 1222 (S.D. Fla. 1994).

Florida Key Deer v. Brown, 364 F.Supp.2d 1345 (S.D. Fla. 2005).

Goble, D. D., and J. M. Scott. 2006. Recovery management agreements offer alternative to continuing ESA listings. Fisheries 31: 35-36.

Goble, D. D., J. A. Wiens, J. M. Scott, T. D. Male, and J. A. Hall. 2012. Conservation-reliant species. BioScience 62: $869-873$.

Rohlf, D. J. 2001. Jeopardy under the Endangered Species Act: Playing a game protected species can't win. Washburn Law Journal 41:114-163.

Ruhl, J. B. 1995. Section 7(a)(1) of the "new" Endangered Species Act: Rediscovering and redefining the untapped power of Federal agencies' duty to conserve species. Environmental Law 25:1107-1163.

Sierra Club v. Glickman, 156 F. 3d 606, 5th Cir. 1998, http://caselaw.findlaw.com/us-5th-circuit/1106766.html.

TVA v. Hill, 437 U.S. 153, 1978, http://caselaw.lp.findlaw.com/scripts/getcase.pl? court=US\&vol=437\&invol=153.

U.S. Army Corps of Engineers (USACE). 2013. Conservation plan for the Interior Least Tern, pallid sturgeon, and fat pocketbook mussel in the Lower Mississippi River (Endangered Species Act, section 7(a)(1)). Vicksburg, MS: U.S. Army Corps of Engineers, Mississippi Valley Division.

U.S. Fish and Wildlife Service (USFWS). 2013. Interior Least Tern (Sternula antillarum): 5-year review: summary and evaluation. Jackson, MS:U.S. Fish and Wildlife Service, Southeast Region, Mississippi Field Office. https://www.fws.gov/southeast//pdf/five-year-reviews/interior-least-tern.pdf (accessed 17 September 2018).

U.S. Marine Corps (USMC). 2012. Red-cockaded Woodpecker (Picoides borealis) recovery and sustainment program. Marine Corps Base Camp Lejeune, CA: Marine Corps Installations East.

Wood, M. C. 2004. Protecting the wildlife trust: A reinterpretation of section 7 of the Endangered Species Act. Environmental Law 34:604-645. 
Appendix I. Attendees at the Workshop of Threatened and Endangered Species Team Workshop on ESA Section 7(a)(1) Conservation Planning in the South Pacific Division, December 6-7, 2016, at The Marine Corps Base Camp Pendleton, CA.

\begin{tabular}{|c|c|c|}
\hline Attendees & Agencyl & ganization \\
\hline Arnold, Arlene & DoD & Navy \\
\hline Avery, Jon & USFWS & Carlsbad Ecological Services Office, CA \\
\hline Barron, Michael & DoD & Marine Corps Base Camp Pendleton \\
\hline Battista, Bart & DoD & Marine Corps Base Camp Pendleton \\
\hline Beck, Peter & USFWS & Carlsbad Ecological Services Office, CA \\
\hline Berry, Bill & DoD & Marine Corps Base Camp Pendleton \\
\hline Bieber, Deborah & DoD & Marine Corps Base Camp Pendleton \\
\hline Biondolillo, John & DoD & Marine Corps Base Camp Pendleton \\
\hline Booker, Melissa & DoD & Navy, San Celmente Island \\
\hline Brennan, Michael & DoD & Readiness and Environmental Protection Integration \\
\hline Britzke, Eric & USACE & Engineer Research and Development Center-EL \\
\hline Brumback, Darren & NOAA & National Marine Fisheries Service, West Coast Office \\
\hline Bryant, Shannon & DoD & Marine Corps Base Camp Pendleton \\
\hline Bush, Rich & NOAA & National Marine Fisheries Service, West Coast Office \\
\hline Cavanaugh, Jennifer & USDA & National Resources Conservation Service, CA \\
\hline Cie, Damien & DoD & Marine Corps Base Camp Pendleton \\
\hline Clark, Denise & USGS & San Diego Office \\
\hline Cleary-Rose, Karin & USFWS & Carlsbad Ecological Services Office, CA \\
\hline Clifford, Jodi & USACE & Los Angeles District \\
\hline Degregorio, Brett & USACE & Engineer Research and Development Center-CERL \\
\hline Doherty, Lillian & USACE & Los Angeles District \\
\hline Draguesku, Michelle & USFWS & R8, Carlsbad ES Office \\
\hline Eckenroad, Collen & DoD & Marine Corps Base Camp Pendleton \\
\hline Fejeran, James & DoD & U.S. Marine Corps, Barstow \\
\hline Ferguson, Nancy & USFWS & R8, Carlsbad ES Office \\
\hline Fischer, Richard & USACE & Engineer Research and Development Center-EL \\
\hline Goebel, Karen & USFWS & Carlsbad Ecological Services Office \\
\hline Gower, Pat & USFWS & Carlsbad Ecological Services Office \\
\hline Graham, James & FEMA & $\begin{array}{l}\text { Office of Environmental Planning and Historic } \\
\text { Preservation }\end{array}$ \\
\hline Haase, Bob & DoD & Marine Corps Base Camp Pendleton \\
\hline Hartfield, Paul & USFWS & Mississippi Field Office \\
\hline
\end{tabular}


ERDC/TN DOER-E43

February 2019

Herbst, Chris

Hobbs, Rob

Hoffman, Scott

Hoyer, William

Irvin, Andrew

Jones, Christopher

Jung, Jake

Kean, Joseph

Keeney, Thomas

Kughen, Katy

Kus, Barbara

Lee, Colin

Leslie, Benjamin

Levi, Dean

Likins, Benjamin

Lorne, Matt

Lott, Casey

Matsuda, Trina

McCall, Tad

McConnell, Patrick

McKessey, Anika

McReynolds, Ryan

Moore, Sharon

Moore, Thomas

Munson, Bryan

Nieto, Michael

Okeefe, Shea

Orndorf, Ryan

Powers, Doug

Prestera, Wendy

Raitter, Bill

Richardson, Mary

Ricks, Stephen

Roberson, Aimee

Ruane, Martin

Ruvelas, Penny

Sabol, Thomas
DoD USA-Preta Env

RECON Environmental, Inc.

USFWS Carlsbad Ecological Services Office, CA

DoD Naval Base, Ventura County, CA

DoD U.S. Marine Corps, Mountain Welfare Training Center

USACE Los Angeles District

USACE Engineer Research and Development Center-EL

Tierra Data, Inc.

USACE Los Angeles District

USFWS Carlsbad Ecological Services Office

USGS Western Ecological Research Center

DoD Marine Corps Base Camp Pendleton

DoD U.S. Marine Corps, Barstow

DoD Marine Corps Base Camp Pendleton

DoD Marine Corps Base Camp Pendleton

DoD Marine Corps Base Camp Pendleton

ABC American Bird Conservancy

USGS San Diego

DoD Readiness and Environmental Protection Integration

DoD Marine Corps Base Camp Pendleton

DoD Marine Corps Base Camp Pendleton

USFWS Consultation \& Conservation Planning Division

$\mathrm{DoD}$

USDA National Resources Conservation Service, CA

DoD Naval Base Coronado

RECON Environmental, Inc.

USDA Escondido Field Office, CA

DoD Readiness and Environmental Protection Integration

DoD Naval Facilities Southwest

DoD Marine Corps Base Camp Pendleton

DoD Marine Corps Base Camp Pendleton

USFWS Ecological Services Office, AZ

USFWS Mississippi Field Office

ABC American Bird Conservancy

DoD Navy, Point Mugu

NOAA National Marine Fisheries Service, West Coast Office

DoD Naval Facilities Southwest 
Salz, Ron

Sandoval, Lisa

Sanzenbacher, Pete

Schallmann, Bob

Searcy, Ariel

Shepherd, Tiffany

Smith, David

Snyder, Jonathon

Sosa, Roland

Souther, Andrea

Spangle, Steve

Stadtlander, Doreen

Struck, Brittany

Sullivan, Sherri

Swannack, Todd

Teachout, Emily

Thogerson, Collette

Thomas, Kristin

Vissman, Sandy

Whitaker, Terressa

Winterhouse, Matt

Wirsching, Angela

Wolff, Pat

Yates, Chris

Younkman, David

Zoutendyk, David

Zych, Alisa
NOAA ESA Cooperative Division

USACE Los Angeles District

USFWS R8, Carlsbad ES Office

DoD Naval Weapons Station Seal Beach

Marstel-Day, LLC

DoD Naval Base Coronado

USACE Engineer Research and Development Center-EL

USFWS Carlsbad Ecological Services Office, CA

DoD Navy

DoD Marine Corps Base Camp Pendleton

USFWS Ecological Services Office, AZ

USFWS R8, Carlsbad ES Office

NOAA National Marine Fisheries Service, West Coast Office

DoD Marine Corps Base Camp Pendleton

USACE Engineer Research and Development Center-EL

USFWS Consultation and Conservation Planning Division

USFWS South Coast Division, Ventura, Co, CA

DoD Marine Corps Base Camp Pendleton

USFWS R8, Carlsbad ES Office

RECON Environmental, Inc.

DoD Marine Corps Base Camp Pendleton

DoD Naval Facilities Southwest

USACE Engineer Research and Development Center-CERL

NOAA National Marine Fisheries Service, West Coast Office

ABC American Bird Conservancy

USFWS R8, Carlsbad ES Office

DoD Marine Corps Base Camp Pendleton

NOTE: The contents of this technical note are not to be used for advertising, publication, or promotional purposes. Citation of trade names does not constitute an official endorsement or approval of the use of such products. 